\title{
PENGARUH BERBAGAI JENIS ATRAKTAN PADA LETHAL OVITRAP TERHADAP NYAMUK YANG TERPERANGKAP DI KELURAHAN KARANGKLESEM KECAMATAN PURWOKERTO SELATAN KABUPATEN BANYUMAS TAHUN 2016
}

\author{
Isna Fadlilah*), Aris Santjaka **), Arif Widyanto **) \\ Jurusan Kesehatan Lingkungan, Politeknik Kesehatan Kemenkes Semarang, \\ Jl.Raya Baturaden KM 12 Purwokerto, Indonesia
}

\begin{abstract}
Abstrak
Latar Belakang di Kelurahan Karangklesem, Kecamatan Purwokerto Selatan, Kabupaten Banyumas telah terjadi 20 kasus DBD pada tahun 2015. Pengendalian vektor penyakit DBD selama ini dititikberatkan pada pengendalian kimia yang mana dapat berdampak pada lingkungan. Salah satu pengendalian yang aman yaitu menggunakan lethal ovitrap dengan berbagai jenis atraktan. Tujuan penelitian ini untuk mengetahui pengaruh berbagai jenis atraktan pada Iethal ovitrap terhadap jumlah nyamuk yang terperangkap. Penelitian eksperimen digunakan dalam penelitian ini dengan menggunakan quasi ekperimental design dengan design penelitian quasi time series design selama 14 hari sejak lethal ovitrap diletakkan . Hasil penelitian didapatkan 71 ekor nyamuk (97\%) pada lethal ovitrap yang berisi atraktan air rendaman jerami, 3 ekor nyamuk (3\%) pada lethal ovitrap yang berisi air setempat dan pada atraktan air rendaman gula tidak terdapat nyamuk satupun. Hal itu berarti dari ketiga atraktan tersebut air rendaman jerami yang memiliki daya tarik lebih kuat bagi nyamuk. Simpulan penelitian ada perbedaan jumlah nyamuk yang terperangkap pada lethal ovitrap berdasarkan jenis atraktan. Sebaiknya air rendaman jerami sebagai atraktan dalam lethal ovitrap untuk menarik nyamuk dibandingkan dengan atraktan air setempat dan air rendaman gula.
\end{abstract}

Kata kunci: atraktan, dan lethal ovitrap

\begin{abstract}
THE EFFECT OF VARIOUS TYPES OF ATTRACTANT ON LETHAL OVITRAP TOWARDS THE NUMBER OF TRAPPED MOSQUITOES IN KARANGKLESEM VILLAGE PURWOKERTO SOUTH DISTRICT, DISTRICT BANYUMAS 2016. In Karangklesem Village, South District Purwokerto, Banyumas there have been 20 cases of Dengue Hemorrhagic Fever in 2015. Disease vector Dengue Hemorrhagic Fever control has been focused on chemical control where it impacts on the environment. One safe control is using lethal ovitrap with different kinds of attractant. The purpose of this study is to determine the effect of various types of attractant on Iethal ovitrap towards the number of trapped mosquitoes. Experimental research used in this study by using a quasi experimental design to design quasi time series design for 14 days from lethal ovitrap laid. The research results are 71 mosquitoes (97\%) on lethal ovitrap filled with hay soaking water attractant, 3 mosquitoes (3\%) on lethal ovitrap filled with local water and there are no mosquitoes on sugar soaking water attractant. It means, from the 3 attractants, the hay soaking water is high attracted for mosquitoes. The research conclusion is there is a difference amount of trapped mosquitoes on lethal ovitrap according to the attractant. Preferably, hay soaking water as attractants in lethal ovitrap to attract mosquitoes compared with local water attractants and sugar soaking water attractants.
\end{abstract}

Keywords : attractant, and lethal ovitrap

\footnotetext{
${ }^{*}$ E-mail: isnafadlilah7@ gmail.com

${ }^{* *}$ E-mail: arissantjaka@gmail.com

${ }^{* * *)}$ E-mail: arifwidyanto74@yahoo.com
} 


\section{PENDAhuluan}

Demam Berdarah Dengue merupakan penyakit menular yang dapat menyebabkan risiko kematian tinggi. Kejadian kasus DBD di Kabupaten Banyumas tahun 2015 terhitung sejak bulan Januari sampai September menyebutkan bahwa Kecamatan tertinggi yaitu Kecamatan Purwokerto Selatan dengan jumlah kasus sebanyak 96 (IR 1,25 per 1000 penduduk). Karangklesem merupakan salah satu kelurahan di Kecamatan Purwokerto Selatan dengan kasus DBD yang cukup tinggi yaitu sebanyak 20 kasus.

Kasus DBD tahun 2015 perlu upaya pengendalian yang lebih luas. Berbagai upaya telah dilakukan oleh instansi kesehatan untuk memutus rantai penularan demam berdarah diantaranya dengan penemuan dan pengobatan penderita, pengendalian vektor dan kerja sama lintas sektor (Departemen Kesehatan Republik Indonesia, 2005). Upaya pengendalian dapat dilakukan antara lain dengan cara fisik, kimia dan biologi. Akan tetapi sampai sekarang pengendalian masih dititikberatkan pada penggunaan insektisida kimia yang berulang-ulang menimbulkan masalah baru pada lingkungan dan manusia. Dampak negatif yang ditimbulkan oleh insektisida kimia tersebut mendorong para pakar untuk mencari alternatif pemberantasan vektor yaitu dengan cara pengendalian yang aman dan tidak menimbulkan masalah yang baru dengan pengendalian fisik yaitu menggunakan lethal/autocidal ovitrap dengan berbagai jenis atraktan. Penggunaan lethal ovitrap serupa dilakukan Tarmali (1996) di Yogyakarta dan berhasil menurunkan HI (House Index), CI (Container Index), dan BI (Breteau Index) sebesar $61,49 \%, 50,91 \%$,dan $53,62 \%$.

Tujuan dari penelitian ini yaitu untuk mengetahui pengaruh berbagai jenis atraktan pada lethal ovitrap terhadap nyamuk yang terperangkap.

\section{BAHAN DAN METODE}

Variabel independen dalam penelitian ini yaitu jenis atraktan pada lethal ovitrap (air rendaman jerami, air rendaman gula pasir, dan air setempat) dan variabel dependen yaitu jumlah nyamuk yang terperangkap. Jenis penelitian ini adalah penelitian eksperimen dengan kualifikasi quasi experimental design. Desain yang dipilih the posttest-only control group design. Pengambilan sampel menggunakan metode purposive sampling, yang harus memenuhi beberapa kriteria yaitu Desa dengan kasus DBD yang tinggi dan Kasus DBD yang penularannya cluster. Kelurahan Karangklesem merupakan kelurahan dengan kasus DBD yang tinggi yaitu ada 20 kasus. Kasus DBD tersebut sekian kasus tersebar, sekian kasus cluster. Apabila penularan penyakit menular terutama yang ditularkan oleh nyamuk maka itu merupakan indikasi terjadi penularan setempat. Kasus cluster terjadi di Kelurahan Karangkesem RW 05 yang mana telah terjadi 2 kasus DBD di 2 rumah.

Pemasangan lethal ovitrap dilakukan dilakukan di RW 05 dengan jumlah rumah responden 10 rumah yaitu 2 rumah penderita dan 8 rumah disekitar penderita. Pengambilan sampel rumah di sekitar penderita dengan dibuat titik tengah, yang mana titik tengah tersebut adalah salah satu rumah penderita, kemudian ditarik garis lurus ke berbagai sisi (kanan, kiri, depan dan belakang) sejauh 100 meter dan disetiap sisi diambil 2 rumah yang terdekat dengan rumah penderita. Data diperloleh dengan cara perhitungan, observasi, dan pengukuran. Instrument yang digunakan berupa alat perhitungan, checklist, lux meter, thermohigrometer. Pengolahan data yang digunakan uji anova one way.

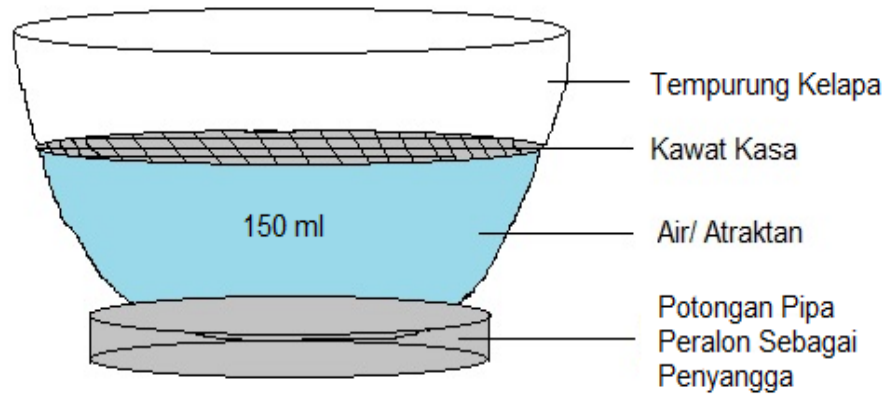

Gambar 1. Desain Lethal Ovitrap

\section{HASIL DAN PEMBAHASAN}

Penelitian ini dilakukan dengan cara menghitung jumlah nyamuk yang terperangkap pada lethal ovitrap yang dipasang diseluruh rumah responden berdasarkan jenis atraktan, selain itu juga dilakukan pengukuran suhu, kelembaban, dan intensitas cahaya pada setiap pengamatan. Pengamatan dilakukan pada hari ke 4,8,10,12, dan 14. 


\section{Pengukuran Suhu}

Pengukuran suhu dilaksanakan pada pukul 15.30-18.00 WIB disetiap rumah responden menggunakan alat thermohygrometer. Suhu di dalam rumah responden berkisar antara $27,4^{\circ} \mathrm{C}-28,4^{\circ} \mathrm{C}$. Suhu udara rata-rata tertinggi saat penelitian berlangsung adalah $28,4^{\circ} \mathrm{C}$. Suhu udara selama penelitian cenderung naik turun hal ini dikarenakan keadaan cuaca yang tidak stabil saat pengukuran.

Nyamuk merupakan hewan berdarah dingin, maka suhu lingkungan sangat berpengaruh terhadap proses metabolisme dan siklus hidup nyamuk. Menurut Dewi (2011) dalam Sovi Milasari (2014) rata-rata suhu optimum untuk pertumbuhan nyamuk yaitu berkisar antara $25^{\circ} \mathrm{C}$ sampai $27^{\circ} \mathrm{C}$. Nyamuk dapat bertahan hidup pada suhu yang rendah tetapi proses metabolismenya akan turun. Pada suhu kurang dari $16^{\circ} \mathrm{C}$ dan lebih tinggi dari $32^{\circ} \mathrm{C}$ nyamuk akan mengalami gangguan pertumbuhannya. Pada suhu diatas $35^{\circ} \mathrm{C}$, nyamuk dapat mengalami perubahan yaitu lambatnya proses fisiologi. Pertumbuhan akan terhenti bila suhu kurang dari $10^{\circ} \mathrm{C}$ atau diatas $40^{\circ} \mathrm{C}$ serta nyamuk mempunyai toleransi suhu berkisar $5^{0} \mathrm{C}-6^{\circ} \mathrm{C}$. Suhu juga dapat berpengaruh pada umur nyamuk, suhu optimum nyamuk antara $20^{\circ} \mathrm{C}-25^{\circ} \mathrm{C}$, apabila suhu dinaikkan umur nyamuk akan lebih pendek, dengan demikian mortalitas nyamuk akan semakin banyak. (Aris Santjaka, 2013)

Hasil pengukuran suhu rata-rata per rumah yaitu antara $27,4^{0} \mathrm{C}-28,4^{\circ} \mathrm{C}$. Hasil pengukuran tersebut diatas suhu optimum perkembangan nyamuk, tetapi masih dalam batas toleransi nyamuk.

\section{Pengukuran Kelembaban}

Pengukuran kelembaban dilaksanakan pada pukul 15.30-18.00 WIB disetiap rumah responden menggunakan alat thermohygrometer. Kelembaban di dalam rumah responden berkisar antara 92\%-92,6\%. Kelembaban rata-rata tertinggi saat penelitian berlangsung yaitu $92,6 \%$.

Nyamuk pada umumnya menyukai kelembaban diatas 60\%, karena pada kelembaban $<60 \%$ umur nyamuk akan menjadi lebih pendek, sehingga siklus pertumbuhan parasit tidak terbentuk. (Departemen Kesehatan Republik Indonesia, 2007). Pada kelembaban yang tinggi nyamuk menjadi lebih aktif dan lebih sering menggigit sehingga akan mempercepat proses perkembangbiakan nyamuk.

Hasil pengukuran kelembaban yaitu berkisar antara 92\%-92,6\% yang mana sangat cocok untuk perkembangan hidup nyamuk karena diatas $60 \%$.

3. Pengukuran Intensitas Cahaya

Pengukuran intensitas cahaya dilaksanakan pada pukul 15.30-18.00 WIB disetiap rumah responden menggunakan alat luxmeter. Intensitas cahaya di rumah responden berkisar antara 0,2-10 lux. Intensitas cahaya rata-rata tertinggi saat penelitian berlangsung yaitu 10 lux.

Nyamuk mempunyai kebiasaan beristirahat ditempat yang gelap dan lembab seperti yang dijelaskan oleh Cecep Hadi Sucipto (2011, h.50).

Hasil pengukuran terbukti bahwa nyamuk menyukai tempat yang gelap dan redup sebagai tempat untuk istirahat setelah menghisap darah dan kemudian bertelur.

\section{Pemasangan Lethal Ovitrap}

Pemasangan lethal ovitrap dilakukan di Kelurahan Karangklesem di 10 rumah responden, dimana setiap rumah dipasang 3 lethal ovitrap dengan atraktan yang berbedabeda yaitu air rendaman jerami, air rendaman gula, dan air setempat. Lethal ovitrap tersebut diletakkan di dekat kamar mandi yang mana penempatannya harus memenuhi kriteria yaitu tempatnya gelap, lembab, dan sedikit angin. Pemasangan dilaksanakan selama 14 hari. Lethal ovitrap diletakkan berdekatan satu sama lain yang nantinya akan dilihat lethal ovitrap dengan atraktan mana yang lebih banyak menarik nyamuk untuk datang dan menetaskan telurnya. Telur nyamuk tersebut akan dibiarkan menetas menjadi larva dan berubah menjadi pupa lalu tumbuh menjadi nyamuk dewasa dan nyamuk dewasa yang berada di dalam lethal ovitrap tidak dapat terbang keluar karena terhalang oeh kawat kassa dan lama kelamaan akan mati dengan sedirinya. Nyamuk tersebut mati dapat dikarenakan yaitu antara lain: (a) nyamuk yang menetas dari pupa tidak dapat terbang keluar sehingga terendam oleh atraktan kemudian mat, (b) tidak memperoleh makanan karena terperangkap didalam lethal ovitrap sehingga proses metabolisme tidak berjalan lalu nyamuk akan mati, (c) bagian tubuh nyamuk rusak karena mencoba keluar kemudian menabrak kawat kassa sehingga anggota tubuh seperti wing rusak dan akhirnya nyamuk jatuh ke permukaan air/atraktan kemudian lama kelamaan akan mati.

5. Jumlah Nyamuk yang Terperangkap

a. Jumlah Larva

Berikut merupakan jumlah larva yang terdapat dalam lethal ovitrap : 
Tabel 1: Hasil pengamatan jumlah larva yang terdapat di lethal ovitrap

\begin{tabular}{ccccc}
\multicolumn{5}{c}{ berdasarkan jenis atraktan } \\
\hline \multirow{2}{*}{ No } & Kode Rumah & Jerami & Gula Pasir & Air Setempat \\
\hline 1 & & 83 & 0 & 0 \\
2 & P1 & 26 & 0 & 0 \\
3 & P2 & 46 & 0 & 0 \\
4 & S1 & 113 & 0 & 0 \\
5 & S2 & 60 & 0 & 0 \\
6 & B1 & 19 & 0 & 14 \\
7 & B2 & 430 & 0 & 0 \\
8 & T2 & 37 & 0 & 0 \\
9 & U1 & 58 & 0 & 0 \\
10 & U2 & 28 & 0 & 0 \\
\hline \multicolumn{7}{c}{ Jumlah } & 900 & 0 & 14 \\
& Total & & 914 ekor
\end{tabular}

\section{Persentase Larva yang Terdapat Pada Lethal Ovitrap Dibedakan Menurut Jenis Atraktan}

$\square$ air rendaman jerami $\square$ air rendaman gula pasir $\square$ air setempat

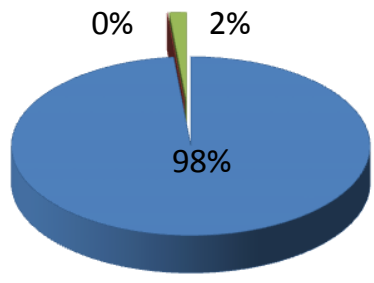

Gambar 2. Grafik Jumlah Larva yang Terdapat Pada Lethal Ovitrap Dibedakan Menurut Jenis Atraktan

Larva yang didapat selama 14 hari pemasangan lethal ovitrap yaitu sejumlah 914 ekor. Lethal ovitrap berisi air rendaman jerami mendapat sebanyak 900 ekor larva (98\%) dan pada air rendaman gula pasir tidak mendapatkan larva satupun $(0 \%)$, sedangkan pada lethal ovitrap berisi air setempat sebagai kontrol terdapat sebanyak 14 ekor $(2 \%)$.

b. Jumlah Pupa

Berikut merupakan hasil pupa yang terdapat dalam lethal ovitrap :

Tabel 2 Hasil pengamatan jumlah pupa yang terdapat di lethal ovitrap berdasarkan jenis atraktan.

\begin{tabular}{lcccc}
\hline \multirow{2}{*}{ No } & Kode Rumah & Jerami & Jenis Atraktan \\
\hline$(1)$ & $(2)$ & $(3)$ & $(4)$ & Air Setempat \\
\hline 1 & P1 & 5 & 0 & 0 \\
2 & P2 & 13 & 0 & 0 \\
3 & S1 & 6 & 0 & 0 \\
4 & S2 & 17 & 0 & 0 \\
5 & B1 & 15 & 0 & 0 \\
6 & B2 & 4 & 0 & 5 \\
7 & T1 & 43 & 0 & 0 \\
\hline
\end{tabular}




\begin{tabular}{lcccc}
\hline$(1)$ & $(2)$ & $(3)$ & $(4)$ & $(5)$ \\
\hline 8 & $\mathrm{~T} 2$ & 4 & 0 & 0 \\
9 & $\mathrm{U} 1$ & 11 & 0 & 0 \\
10 & $\mathrm{U} 2$ & 10 & 0 & 0 \\
\hline \multicolumn{7}{c}{ Jumlah } & 128 & 0 & 5 \\
& TOTAL & & 133 ekor \\
\hline
\end{tabular}

\section{Persentase Jumlah Pupa yang Terdapat Pada Lethal Ovitrap Dibedakan Menurut Jenis Atraktan}

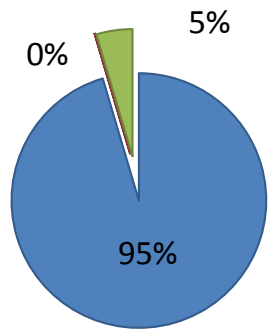

$\square$ Air Rendaman Jerami $\square$ Air Rendaman Gula Pasir $\square$ Air Setempat

Gambar 3. Grafik Persentase Jumlah Pupa yang Terdapat Pada Lethal Ovitrap Dibedakan Menurut Jenis Atraktan

Jumlah pupa yang terperangkap pada lethal ovitrap yaitu sejumlah 133 ekor. Lethal ovitrap yang berisi atraktan air rendaman jerami mendapat 128 ekor pupa $(95 \%)$ dan pada air rendaman gula pasir tidak mendaat pupa satupun $(0 \%)$ sedangkan pada lethal ovitrap berisi air setempat sebagai kontrol terdapat sebanyak 5 ekor $(5 \%)$.

c. Jumlah Nyamuk Dewasa

Berikut merupakan jumlah nyamuk yang terperangkap dalam lethal ovitrap :

Tabel 3. Hasil pengamatan jumlah nyamuk dewasa yang terdapat di lethal ovitrap berdasarkan jenis atraktan

\begin{tabular}{|c|c|c|c|c|}
\hline \multirow[b]{2}{*}{ No } & \multirow[b]{2}{*}{ Kode Rumah } & \multicolumn{3}{|c|}{ Jenis Atraktan } \\
\hline & & Jerami & Gula & $\begin{array}{c}\text { Air } \\
\text { Setempat }\end{array}$ \\
\hline 1 & P1 & 8 & 0 & 0 \\
\hline 2 & $\mathrm{P} 2$ & 4 & 0 & 0 \\
\hline 3 & S1 & 5 & 0 & 0 \\
\hline 4 & S2 & 9 & 0 & 0 \\
\hline 5 & B1 & 7 & 0 & 0 \\
\hline 6 & B2 & 6 & 0 & 2 \\
\hline 7 & $\mathrm{~T} 1$ & 17 & 0 & 0 \\
\hline 8 & $\mathrm{~T} 2$ & 6 & 0 & 0 \\
\hline 9 & U1 & 4 & 0 & 0 \\
\hline 10 & U2 & 5 & 0 & 0 \\
\hline & Jumlah & 71 & 0 & 2 \\
\hline & TOTAL & & 73 ekor & \\
\hline
\end{tabular}




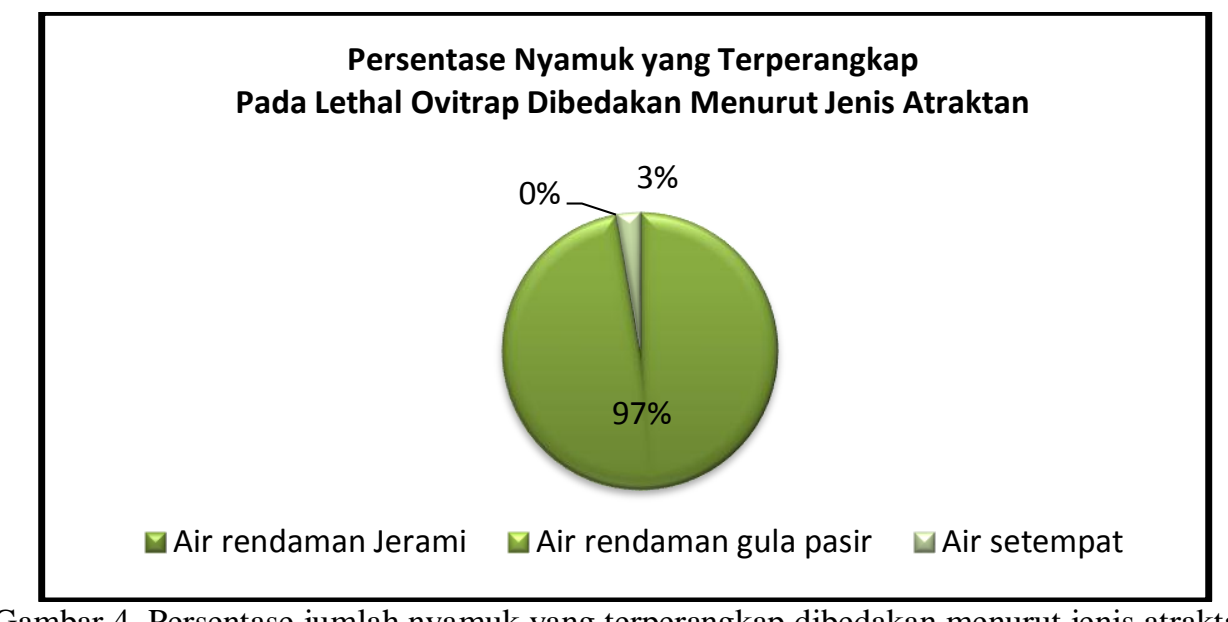

Gambar 4. Persentase jumlah nyamuk yang terperangkap dibedakan menurut jenis atraktan

Jumlah nyamuk dewasa yang terperangkap pada lethal ovitrap yaitu sejumlah 73 ekor. Lethal ovitrap yang berisi atraktan air rendaman jerami mendapat 71 ekor nyamuk dewasa $(97 \%)$ dan pada air rendaman gula pasir tidak mendapat nyamuk dewasa satupun $(0 \%)$ sedangkan pada lethal ovitrap berisi air setempat sebagai kontrol terdapat sebanyak 2 ekor (3\%)

Banyaknya larva, pupa dan nyamuk dewasa yang terperangkap menunjukkan jumlah telur yang diletakkan, menetas menjadi larva kemudian tumbuh menjadi pupa dan nyamuk dewasa. Hal ini berarti bahwa nyamuk betina gravid yang bertelur pada lethal ovitrap berisi air rendaman jerami lebih banyak daripada lethal ovitrap yang berisi jenis atraktan lainnya. Dengan kata lain, atraktan air rendaman jerami memiliki daya tarik yang lebih kuat dari pada air rendaman gula pasir dan air setempat. Hal ini terjadi karena air rendaman jerami mengalami proses metabolisme yang menghasilkan zat berupa ammonia dan $\mathrm{CO}_{2}$, tanda visual ini diterima oleh reseptor nyamuk sehingga memutuskan untuk bertelur pada lethal ovitrap dengan atraktan tersebut. Zat disebut atraktan apabila nyamuk betina gravid menunjukkan gerakan aktif menuju sumbernya untuk meletakkan telur.

Lethal ovitrap yang dipasang mengeluarkan bau tidak enak seperti yang dikatakan oleh beberapa responden. Bau tersebut diindikasikan berasal dari atraktan air rendaman jerami karena proses dekomposisi yang lama. Bau tersebut ditangkap oleh antena nyamuk dimana terdapat sensilla yang mengandung saraf ORNs (Olfactory Receptor Neurons). Saraf sensorik ini menghantarkan impuls kimia dari perifer ke lobus antenna kemudian masuk ke dalam sendillum. Bau berikatan dengan OBPs (Odorant Binding Proteins) melewati cairan lymph menuju dendrite. Ketika kompleks bau OBPs mencapai membran dendrite, bau akan berikatan dengan reseptor transmembran, kemudian ditransfer ke permukaan membran intracellular. Selanjutnya impuls elektrik tersebut disampaikan ke pusat otak untuk menghasilkan respon tingkah laku yang tepat. (Jacquin and Jolly, 2004)

Air rendaman gula pasir tidak mendapat larva satupun, sedangkan air setempat hanya 1 rumah yang positif terdapat larva yaitu sebanyak 14 ekor. Ketiga lethal ovitrap diletakkan berdekatan, hal tersebut berpengaruh terhadap daya tarik nyamuk untuk menaruh telurnya karena bau khas dari air rendaman jerami yang paling menyengat maka nyamuk lebih tertarik kepada air rendaman jerami sehingga atraktan yang lain diabaikan.

Selain itu jenis gula pasir juga berpengaruh, jenis gula pasir yang digunakan dalam penelitian ini adalah gula pasir yang berwarna lebih putih (gula rafinasi), perlu dilakukan penelitian lebih lanjut mengenai jenis gula pasir antara gula pasir yang warnanya kecoklatan (raw sugar) dengan gula pasir yang berwarna lebih putih (gula rafinasi) untuk mengetahui perbedaan jenis gula pasir mana yang paling dapat menarik nyamuk lebih banyak. Selain itu diindikasikan pada gula pasir rafinasi mengandung bahan pemutih sehingga bahan pemutih tersebut menghalangi proses dekomposisi.

Air setempat merupakan habitat asli nyamuk Aedes sp. Air setempat yang digunakan dalam penelitian ini adalah air yang berasal dari PDAM. Hasil pengukuran sisa chlor pada air PDAM tersebut yaitu 0,2 ppm. Air setempat hanya mendapat sedikit nyamuk yang terperangkap diindikasikan masih terdapat kandungan sisa chlor pada air tersebut, kemungkinan larva tidak tahan pada kandungan sisa chlor sehingga tidak dapat berkembangbiak dengan baik. 


\section{Uji Statistik}

Uji statistik yang digunakan adalah uji One way Anova. Hasil uji One way Anova diperoleh $(\mathrm{p}=0,000) \leq(\alpha=0,05)$, maka Ho ditolak artinya ada perbedaan yang signifikan. Karena Ho di tolak maka dilanjutkan dengan uji LSD untuk mengetahui perbedaan pada masing-masing lethal ovitrap yang berisi air rendaman jerami, air rendaman gula pasir, dan air setempat sebagai kontrol. Dari hasil uji LSD tersebut diperoleh hasil sebagai berikut :

a) Air rendaman jerami dibandingkan dengan air rendaman gula pasir

Air rendaman jerami dibandingkan dengan air rendaman gula pasir memiliki nilai beda mean $=0,80912$ dengan nilai signifikansinya $(\mathrm{p}=0,000) \leq(\alpha=0,05)$ artinya ada perbedaan yang signifikan antara air rendaman jerami dengan air redaman gula pasir. Hal tersebut berarti atraktan air rendaman jerami dapat menarik nyamuk kedalam lethal ovitrap sebesar 0,80912.

Jumlah nyamuk dewasa pada lethal ovitrap yang berisi air rendaman jerami sejumlah 71 ekor sedangkan pada lethal ovitrap yang berisi air rendaman gula pasir tidak terdapat nyamuk yang terperangkap. Hal tersebut dapat dikarenakan oleh beberapa kemungkinan yaitu sebagai berikut :

1) Air rendaman jerami mengeluarkan bau yang lebih menyengat dibandingkan dengan air rendaman gula pasir. Bau tersebut diterima oleh reseptor nyamuk sehingga memutuskan untuk bertelur pada lethal ovitrap dengan atraktan air rendaman jerami.

2) Kandungan kimia non-volatil pada air rendaman jerami yang mana kandungan kimia tersebut dimungkinkan berasal dari aktivitas mikroorganisme saat proses dekomposisi berlangsung.

3) Jenis gula pasir yang digunakan yaitu gula pasir yang berwarna lebih putih (gula pasir rafinasi), dimungkinkan ada perbedaan kemampuan menarik nyamuk antara gula pasir yang berwarna lebih putih dengan gula pasir berwarna kecoklatan.

b) Air rendaman jerami dibandingkan dengan air setempat

Air rendaman jerami dibandingkan dengan air setempat memiliki nilai beda mean $=0,77902$ dan nilai signifikansinya atau $(\mathrm{p}=0,000) \leq(\alpha=0,05)$ artinya ada perbedaan yang signifikan antara air rendaman jerami dengan air setempat. Hal tersebut berarti atraktan air rendaman jerami dapat menarik nyamuk kedalam lethal ovitrap sebesar 0,77902. Jumlah nyamuk dewasa pada lethal ovitrap yang berisi air rendaman jerami sejumlah 71 ekor sedangkan pada lethal ovitrap yang berisi air setempat sejumlah 2 ekor nyamuk yang terperangkap. Hal tersebut dapat dikarenakan oleh beberapa kemungkinan yaitu sebagai berikut :

1) Air rendaman jerami mengeluarkan bau yang lebih menyengat dibandingkan dengan air setempat. Bau tersebut diterima oleh reseptor nyamuk sehingga memutuskan untuk bertelur pada lethal ovitrap dengan atraktan air rendaman jerami.

2) Kandungan kimia non-volatil pada air rendaman jerami yang mana kandungan kimia tersebut dimungkinkan berasal dari aktivitas mikroorganisme saat proses dekomposisi berlangsung

3) Air setempat yang digunakan dalam penelitian ini berasal dari air PDAM. Air setempat hanya mendapat sedikit nyamuk yang terperangkap dimungkinkan karena dalam air tersebut masih terdapat sisa chlor. Sisa chlor dikhawatirkan dapat mempengaruhi pertumbuhan larva karena sisa chlor bersifat desinfektan untuk beberapa bakteri dan virus.

c) Air setempat dibandingkan dengan air rendaman gula pasir

Air setempat dibandingkan dengan air rendaman gula pasir memiliki nilai beda mean $=0,3010$ dan nilai signifikansinya $(p=0,586) \geq(\alpha=0,05)$ artinya tidak ada perbedaan yang signifikan antara air setempat dengan air redaman gula pasir. Hal tersebut berarti air setempat dapat menarik nyamuk kedalam lethal ovitrap sebesar 0,03010. Jumlah nyamuk dewasa pada lethal ovitrap yang berisi air setempat adalah 2 ekor sedangkan pada lethal ovitrap yang berisi air rendaman gula pasir tidak terdapat nyamuk yang terperangkap. Hal ini dapat dikarenakan yaitu sebagai berikut:

1) Air setempat merupakan salah satu habitat asli nyamuk.

2) Jenis gula pasir yang digunakan yaitu gula pasir yang berwarna lebih putih (gula pasir rafinasi) yang mana dimungkinkan ada perbedaan kemampuan menarik nyamuk antara gula pasir yang berwarna lebih putih dengan gula pasir berwarna kecoklatan. 


\section{SIMPULAN}

Jumlah nyamuk yang terperangkap pada lethal ovitrap yang berisi air rendaman jerami sejumlah 71 ekor (97\%), air rendaman gula tidak memperoleh nyamuk satupun (0\%), dan air setempat memperoleh nyamuk sejumlah 2 ekor (3\%). Hal tersebut berarti atraktan air rendaman jerami yang paling kuat menarik nyamuk.

Hasil penelitian dianalisis dengan menggunakan uji statistic One way Anova . Hasil uji beda jumlah nyamuk yang terperangkap didapatkan nilai $(\mathrm{p}=0,000<\alpha=0,05)$ sehingga Ho ditolak, dan Ha diterima. Artinya ada beda jumlah nyamuk yang terperangkap berdasarkan jenis atraktan. Karena Ho ditolak maka dilanjutkan dengan uji lanjut LSD. Hasil uji statistic LSD antar perlakuan pada penelitian didapatkan hasil yaitu ada beda jumlah nyamuk yang terperangkap antara atraktan air rendaman jerami dengan atraktan air rendaman gula pasir, dan dengan air setempat. Kemudian tidak ada beda jumlah nyamuk yang terperangkap antara atraktan air rendaman gula pasir dengan air setempat.

\section{SARAN}

1. Bagi Masyarakat Kelurahan Karangklesem Penggunaan lethal ovitrap berisi atraktan air rendaman jerami bisa dijadikan alternatif tambahan dalam metode pengendalian vektor DBD dibandingkan dnegan atraktan air rendaman gula dan air setempat. Selain itu lethal ovitrap dapat digunakan sebagai pengganti kegiatan Pemberantasan Sarang Nyamuk (PSN) dan Fogging sebagai pengendalian DBD.

\section{Bagi Tenaga Kesehatan}

Penggunaan lethal ovitrap dengan atraktan bisa dijadikan alternatif tambahan dalam metode pengendalian vektor DBD.

3. Bagi Peneliti Lain

Dapat dilakukan penelitian lebih lanjut mengenai pengaruh lethal ovitrap terhadap penurunan House Index (HI), Container Index (CI), dan Breteau Index (BI) secara nyata.

\section{DAFTAR PUSTAKA}

Aradilla. 2009. Uji Efektivitas Ekstrak Ethanol Daun Mimba (Azadirachta indica) terhadap Larva Aedes aegypti. Skripsi. Fakultas Kedokteran, Universitas Diponegoro.

Astuti, Puji Endang. 2011. Efektivitas Alat Perangkap (Trapping) Nyamuk Vektor Demam Berdarah Dengue dengan Fermentasi Gula. Jurnal Kesehatan Masyarakat Vo. 3 No.1. diakses di http://ejournal.litbang.depkes.go.id/index.php/ aspirator/article/view/2957 pada tanggal 25

November 2015

Azzahra, Fatimah. 2015. Pengaruh Berbagai Jenis Antraktan pada Ovitrap terhadap Jumlah Telur Nyamuk Aedes aegypti yang Tertangkap sebagai Upaya Pengendalian Vektor DBD Tahun 2015. Karya Tulis Ilmiah. Purwokerto : Kementerian Kesehatan RI, Politeknik Kesehatan Kemenkes Semarang, Jurusan Kesehatan Lingkungan Purwokerto.

Badan Pusat Statistik. 2002. KBJI 2002 Klasifikasi Baku Jenis Pekerjaan Indonesia. Jakarta : CV. Nario Sari

Departemen Kesehatan RI. 1992. Petunjuk Teknis Pemberantasan Nyamuk Penular Penyakit Demam Berdarah Dengue. Jakarta : Dirjen PPM dan PLP, Depkes RI.

Departemen Kesehatan RI. 2005. Pencegahan dan Pemberantasan Demam Berdarah Dengue di Indonesia. Jakarta : Dirjen PP dan PL, Depkes RI.

Departemen Kesehatan RI. 2007. Pemberantasan Sarang Nyamuk Demam Berdarah Dengue (PSN DBD). Jakarta : Dirjen PP dan PL, Depkes RI.

Dewi, Susanna \& Sumbiring. 2011. Entomologi Kesehatan (Arthropoda Pengganggu Kesehatan dan Parasit yang Dikandungnya). Jakarta : Universitas Indonesia

Dinas Kesehatan Kabupaten Banyumas. 2015. Data Endemisitas DBD Kabupaten Banyumas Tahun 2014. Banyumas : Dinas Kesehatan Kabupaten Banyumas.

Gandahusada S, dkk. 2006. Parasitologi Kedokteran, Cetakan ke-VI, FKUI, Jakarta

Georghiou GP, Saito T, eds. 1983. Pest resistance to pesticides. New York: Plenum Press.

Handayani, Yeyen. 2010. Pengaruh Berbagai Konsetrasi Air Rendaman Jerami Pada Ovitrap Terhadap Jumlah telur Aedes sp. yang Terperangkap di Pedurungan Kidul, Kota Semarang. Skripsi. Fakultas Kesehatan Masyarakat, Universitas Muhammadiyah Semarang

Iskandar, Adang, 1985, Pemberantasan Serangga Penular dan Binatang Pengganggu, Jakarta : APK-TS Pusdiknakes, Depkes RI.

Jacquin and Jolly. 2004. Insect Olfactory Receptors : Contribution of Molecular Biology to Chemical Ecology. http://www.science.uva.nl. Diakses pada tanggal 31 Januari 2016

Kurniati, Alfi. 2015. Efektivitas Gula Sebagai Atraktan Nyamuk. Skripsi. Medan: Fakultas 
Kesehatan Masyarakat, Universitas Sumatera Utara.

Kementerian Kesehatan RI. 2010. Buletin Jendela Epidemiologi. Jakarta : Pusat Data dan Surveilans Epidemiologi, Kementerian Kesehatan RI

Kementerian Kesehatan R1. 2015. Demam Berdarah Biasanya Meningkat di Januari. Jakarta : Pusat Komunikasi Publik Sekretariat Jenderal Kementerian Kesehatan RI. http://www.depkes.go.id diakses pada tanggal 10 Desember 2015.

Margatan, Arcole. 1996. Mewaspadai Demam Berdarah dan Berbagai Macam Demam Lainnya. Solo : CV. Aneka Solo

Milasari, Sovi. 2014. Pengaruh Modifikasi Antraktan Terhadap Jumlah Telur Nyamuk Aedes sp. yang Terperangkap di Kelurahan Karangpucung, Kecamatan Purwokerto Selatan, Kabupaten Banyumas Tahun 2014. Karya Tulis Ilmiah. Purwokerto : Kementerian Kesehatan RI, Politeknik Kesehatan Kemenkes Semarang, Jurusan Kesehatan Lingkungan Purwokerto

Mulyatno, Kris Cahyo. __. Morfologi, Klasifikasi, Siklus Hidup, Habitat dan Penyakit yang ditularkan oleh Nyamuk Aedes sp. Surabaya : Universitas Airlangga. http://www.itd.unair.ac.id/files/pdf/protocol1/ Aedes.pdf (diakses tanggal 20 Desember 2015)

Palgunadi, Bagus. dan Asih R. 2011. Aedes Aegypti Sebagai Vektor Penyakit Demam Berdarah Dengue. Jurnal Universitas Wijaya Kusuma Surabaya. Vol. 2 (1).

Polson KA, Curtis C, Seng CM, Olson JG, Chanta $\mathrm{N}$, Rawlins SC. The use of Ovitrap Baited with Hay Fusion as a Surveilance Tool for Aedes aegypti Mosquitoes Cambodia Dengue Bulletin 2002. Vol. 26: 178-184.

Rakkang, Yulce dkk. 2013. Efektivitas Lethal Ovitrap terhadap Penurunan Kepadatan Larva Aedes aegypti di Kelurahan Adatongeng Kecamatan Turikale Kabupaten Maros. Makassar : Fakultas Kesehatan Masyarakat, Universitas Hassanudin. http://repository.unhas.ac.id/handle/12345678 9/6068 diakses pada tanggal 25 November 2015

Ridwan, R. Dan Mujida A.M. 2009. Pemetaan dan Analisis Kejadian Demam Berdarah Dengue di Kabupaten Bantaeng Propinsi Sulawesi
Selatan. Makassar : Pascasarjana Universitas Hassanudin.

Salim, Milana dan Tri Baskoro T.S. 2015. Uji Efektifitas padaLethal Ovitrap Terhadap Jumlah Nyamuk dan Daya Tetas Teur Nyamuk Aedes Aegypti. Buletin Penelitian Kesehatan. Vol. 43, No. 3. http://www.ejournal.litbang.depkes.go.id/inde x.php/BPK/article/view/4342 diakses pada tanggal 21 Juni 2016.

Santjaka, Aris. 2013. Malaria Pendekatan Mode Kausalitas. Yogyakarta : Nuha Medika

Santoso U. 2011. Pengaruh Lingkungan Hidup Terhadap Nyamuk Anopheles Pada Proses Transmisi Malaria. Bengkulu: Universitas Bengkulu.

Saputra, Kabul Bayu. 2014. Eksplorasi Spesies Nyamuk Di Selokan Kecamatan Purwokerto Selatan, Kabupaten Banyumas (Studi Kasus pada Perumahan Teluk) Tahun 2014. Karya Tulis Ilmiah. Purwokerto : Kementerian Kesehatan RI, Politeknik Kesehatan Kemenkes Semarang, Jurusan Kesehatan Lingkungan Purwokerto.

Sayono. 2008. Pengaruh Modifikasi Ovitrap Terhadap Jumlah Nyamuk Aedes Terperangkap. Tesis. Program Magister Epidemiologi, Program Pascasarjana Universitas Diponegoro Semarang.

Sithiprasasna R, Mahapibul P, Noigamol C, Perich MJ, Zeinchner BC, Burge B, et al. 2003. Field Evaluation of a Lethal Ovitrap for the Control of Aedes aegypti (Diptera: Culicidae) in Thailand. J Med Entomol 2003 40(4): 455 462.

Soegijanto, Soegeng. 2006. Demam Berdarah Dengue. Surabaya : Airlangga University Press

Sucipto, Cecep Dani. 2011. Vektor Penyakit Tropis. Yogyakarta : Gosyen Publishing

Sudoyono, Aru dkk. 2006. Buku Ajar Ilmu Penyakit Dalam Jilid 3 Edisi 1. Jakarta : Departemen Ilmu Penyakit Dalam, Fakultas Kedokteran Universitas Indonesia.

Sunaryo dan Pramestuti N. Mei 2014. Surveilans Aedes aegypti di Daerah Endemis Demam Berdarah Dengue. Jurnal Kesehatan Masyarakat Nasional Volume 8, No. 8. http://www.portalgaruda.com diakses pada tanggal 25 November 2015.

Supartha. 2008. Pengendalian Terpadu Vektor Virus Demam Berdarah Dengue, Aedes aegypti (Linn) dan Aedes albopictus (Skuse) 
(Diptera:Culicidae). Denpasar : Universitas Udayana. http://dies.unud.ac.id/wpcontent/uploads/2008/09/makalah-suparthabaru.pdf diakses pada tanggal 1 Desember 2015

Sutaryo. 2004. Dengue. Jogjakarta : Universitas Gadjah Mada

Waluyo L. 2005. Mikrobiologi Lingkungan. Malang : UMM Press.

Widiarti, Heriyanto B, Boewono DT. 2011. Peta Resistensi Vektor Demam Berdarah Dengue Aedes Aegypti Terhadap Insektisida Kelompok (Organofosfat, Karbamat, Dan Pyrethroid) di Provinsi Jawa Tengah dan Daerah Istimewa Yogyakarta. Buletin Penelitian Kesehatan 39 (4): 176-89.

Widoyono. 2011. Penyakit Tropis Epidemiologi, Penularan, Pencegahan, \& Pemberantasannya. Jakarta : Erlangga

WHO. 2001. Panduan Lengkap Pencegahan \& Pengendalian Dengue \& DBD. Jakarta : Penerbit Buku Kedokteran EGC.

Yahya, H. 1999. Nyamuk dan Petualangannya. http://www.harunyahya.com/indo/artikel/009. htm diakses pada tanggal 27 Januari 2016

Zulkoni, Akhsin. 2010. Parasitologi. Yogyakarta : Nuha Medika 